\title{
PEMASARAN MELALUI MEDIA ONLINE DI MASA PANDEMI PADA USAHA DAGANG PELUMAS DI BEKASI
}

\author{
Herman Ruslim \\ Program Studi Manajemen, Universitas Tarumanagara Jakarta \\ Email: hermanr@fe.untar.ac.id
}

\begin{abstract}
For many businesses, choosing the right marketing channel is not easy. This is because marketing will have a major impact on business development. Therefore, it must be done as best as possible. In the world of the digital era like now, the internet is the center of many people's activities, online marketing is predicted to be the most effective method. Online marketing is considered capable of expanding its business marketing wings optimally at a much lower cost than offline. Online marketing or often referred to as digital marketing is defined as a marketing strategy that utilizes the internet. Marketing activities to get consumers' attention by utilizing sales through social media, websites and emails.This PKM program is in the form of online marketing information on the lubricant trading business in Bekasi, where this business has experienced a decline in sales due to the pandemic. The purpose of this community service activity is to provide input to this business to start the concept of online marketing in order to fulfill customer desires, namely transacting through online purchases. Through the right online marketing, it can ultimately increase sales and even win the competition. Tarumanagara University as an entrepreneur campus that helps provide funds for the implementation of this community service activity.
\end{abstract}

Keywords: sales, internet, online marketing

Bagi banyak bisnis, memilih jalur pemasaran yang sesuai bukanlah hal yang mudah. Hal ini karena pemasaran akan berpengaruh besar terhadap perkembangan bisnis. Oleh karena itu, harus dilakukan sebaik mungkin. Di dunia era digital seperti sekarang, internet menjadi pusat kegiatan banyak orang, pemasaran online digadang-gadang menjadi metode paling efektif. Pemasaran online dianggap mampu melebarkan sayap pemasaran bisnis secara optimal dengan biaya yang jauh lebih ringan dibandingkan secara offline. Pemasaran online atau sering disebut sebagai pemasaran digital diartikan sebagai strategi pemasaran yang memanfaatkan internet. Kegiatan pemasaran untuk mendapatkan perhatian konsumen dengan memanfaatkan penjualan melalui media sosial, website dan email.

Program PKM ini berupa informasi pemasaran online pada usaha dagang pelumas di Bekasi, dimana usaha ini mengalami dampak penurunan penjualan karena pandemi. Tujuan kegiatan pengabdian kepada masyarakat ini dapat memberikan masukan kepada usaha ini untuk memulai konsep pemasaran secara online agar dapat memenuhi keinginan pelanggan, yaitu bertransaksi melalui pembelian secara online. Melalui pemasaran online yang tepat maka pada akhirnya dapat meningkatkan penjualan bahkan memenangi persaingan. Universitas Tarumanagara sebagai kampus entrepreneur yang membantu penyediaan dana demi terselenggaranya kegiatan pengabdian masyarakat ini.

Kata Kunci: penjualan, internet, pemasaran online

\section{PENDAHULUAN}

Perkembangan dunia internet di belahan dunia membuat terjadinya perubahan cara manusia dalam berkomunikasi, berinteraksi, dan memberikan kemudahan dalam memberikan informasi (Rahma, 2015). Berdasarkan survey yang dibuat oleh We Are Social (2019) pengguna internet di Indonesia mengalami kenaikan sebesar $13 \%$ atau sekitar 17 juta dari tahun 2018, dengan rata- rata pengunaan internet dengan smartphone sebagai device sebesar $60 \%$. Menurut Henri Kasyfi selaku sekjen Asosiasi Penyelenggara Jasa Internet Indonesia (APJII), jumlah pengguna internet di Indonesia tumbuh $10,12 \%$. Berdasarkan sumber yang sama dari total populasi masyarakat Indonesia sebesar 264 juta jiwa, terdapat sebanyak 171,17 juta jiwa atau sebesar 64,8\% yang telah terhubung ke internet. Angka tersebut meningkat dibandingkan dengan tahun sebelumnya dimana penetrasi pengguna internet sebesar 54,86\%. Hal tersebut menandakan perkembangan teknologi, komunikasi, informasi maupun internet disambut baik, dan masyarakat mulai mengadopsi teknologi baru dalam kebutuhan hidupnya sehari-hari (apjii.or.id, 2018). APJII menyatakan kontribusi pengguna internet paling besar di Indonesia terdapat pada pulau Jawa, 
yang menyatakan kontribusi pengguna internet di pulau Jawa sebesar 55,7\%, sedangkan di pulau Sumatera sebesar 21,6\%, pulau Kalimantan 6,8\%, Bali dan Nusa Tenggara 5,2\%, dan pulau Sulawesi, Maluku dan Papua sebesar 10,9\%. Dapat kita simpulkan peranan masyarakat yang berada di pulau Jawa, yang merupakan tempat dari kota-kota besar di Indonesia turut berperan aktif dalam menyikapi perkembangan teknologi dan internet.

Hasil survei yang dilakukan APJII Asosiasi Penyelenggara Jasa Internet Indonesia) juga mendapatkan bahwa dalam mengakses internet, perangkat yang digunakan dapat melalui computer desktop, tablet, laptop pribadi maupun Handphone/ smartphone (APJII, 2018). Hasil survei yang dilakukan oleh APJII, rata- rata pengguna internet di Indonesia menggunakan perangkat smartphone dengan persentase $93.3 \%$, computer desktop 9.6\%, laptop $17.2 \%$, dan tablet 5.2\% untuk terhubung dengan internet setiap harinya. Menurut Ramadhan (2018), Penduduk Indonesia menempati peringkat pertama dalam jumlah pengguna teraktif dalam aplikasi mobile dengan jumlah durasi 250 menit atau 4 jam selama sehari pada tahun 2017. Berdasarkan gambar di bawah ini dapat diartikan bahwa masyarakat Indonesia lebih sering menggunakan internet pada smartphone milikinya, membuktikan bahwa perkembangan dalam smartphonepun berkembang dengan sangat cepat.

Tren pembayaran digital (digital payment) mulai digunakan di berbagai negara termasuk Indonesia. Menurut (Dikdik, 2019) digital payment adalah bentuk pembayaran yang menggunakan media teknologi seperti SMS, Mobile Banking, Internet Banking, Digital Wallet, dan sebagainya. Kegiatan ini dapat dilakukan dengan menggunakan perangkat elektronik smarthpone. Menurut Firdha (2019), pembayaran digital merupakan sebuah cara metode baru sebagai alat transaksi yang diamana para pengguna tidak lagi menggunakan uang kertas maupun cek, sehingga dapat memudahkan para pengguna dan mempercepat proses pembayaran dengan menggunakan aplikasi yang dapat diunduh melalui smartphone masyarakat pun mulai teredukasi dengan sendirinya, didukung juga dengan gadget smartphone merupakan kebutuhan sekunder utama di era sekarang. Menurut Haluan (2019), dalam keuntungan digital payment bisa menggunakan berbagai layanan. Kebebasan dalam mengakses online adalah informasi yang tersaji dapat dilihat kapan saja, oleh siapa saja, dan dimana saja. Hal-hal ini yang pada akhirnya menjadikan bisnis pertokoan atau penjualan secara online menjadi marak. Beberapa kendala belanja secara konvensional rasa-rasanya telah hampir dapat di atasi, misalnya ketika musim hujan, berbelanja tetap dapat dilakukan dari rumah tanpa harus ke lokasi penjual. Sebelum membeli, tampilan dan spesifikasi produk dapat dilihat lebih teliti, administrasi dari penjual biasanya akan siap sedia membantu melalui perbincangan (chat) yang juga dilakukan secara online dan saat itu (real time). Sehingga secara waktu, biaya, dan tenaga, pembeli menjadi lebih mudah dalam mengakses produk yang dibutuhkannya. Begitupula sebaliknya dari pihak penjual, selain kemudahan dalam memasarkan produk ke area pemasaran yang lebih luas, waktu pemasaran lebih besar, dan biaya pun menjadi lebih minim dikarenakan penjual tidak perlu mengeluarkan biaya sewa tempat secara fisik, bahkan memungkinkan penjual untuk tidak memiliki barang jadi yang dijualnya. Penjual cukup menampilkan informasi produk, kemudian setelah transaksi jual beli dilakukan, penjual dapat langsung (yang juga dapat dilakukan) secara online memerintahkan pengiriman barang dari pihak distributor utama ke alamat pembeli.

\section{METODE PELAKSANAAN PKM}

Langkah-langkah/Tahapan Pelaksanaan

a. Memetakan segmen market bisnis anda

Setelah diputuskan siapa yang menjadi segmen usaha dagang ini maka selanjutnya memilih media apa yang akan digunakan dalam pemasaran online-nya. Terdapat empat media online yang dapat digunakan oleh usaha dagang ini, yaitu: website, marketplace, toko online, media social. 
b. Memilih media digital yang tepat

Setelah memahami ke empat media digital yang paling sering digunakan, selanjutnya menentukan pilihan untuk menggunakan salah satu media digital saja, dua atau semuanya.

c. Membangun database customer

Tahapan ini digunakan untuk menjaga pelanggan potensial, karena itulah penting sekali mengumpukan data dan sesekali berikan sesuatu yang bernilai (melalui email misalnya) agar mereka mengingat bisnis usaha dagang ini dan pada saatnya nanti mereka akan membeli.

\section{HASIL DAN LUARAN YANG DICAPAI}

\section{Profil Usaha}

$\begin{array}{ll}\text { Nama } & \text { : Aneka Cahaya Pelumas } \\ \text { Wilayah } & \text { : Jl. Raya Bekasi KM 23 } \\ \text { Kecamatan } & : \text { Kranji } \\ \text { Propinsi } & \text { : Jawa Barat } \\ \text { Jam buka } & : 08.00-17.00 \text { (Hari Senin- Sabtu) }\end{array}$

Aneka Cahaya Pelumas merupakan usaha oli yang mendistribusikan produknya di wilayah Bekasi dan sekitarnya. Usaha ini beroperasi sejak tahun 2014 yang dikelola oleh Bapak Andry dengan dibantu 4 orang karyawannya. Usaha ini berada di Jalan Raya Bekasi KM 23 Bekasi Barat. Produk yang didistribusikan adalah berbagai macam merek oli, antara lain Shell, Castrol, Federal, Evalube, dll. Usaha penjualan oli ini terbilang cukup tinggi mengingat produk oli merupakan "makanan" bagi kendaraan bermotor. Usaha ini melayani konsumen mulai pukul 08.00 sampai dengan 17.00 .

\section{Memetakan segmen market bisnis anda}

Pada bagian ini, tim memberikan pendampingan berupa masukan kepada mitra untuk mengelompokkan jenis pelanggan berdasarkan cirinya, apakah pelanggan bisnis atau pelanggan non-bisnis atau pasar konsumen/produsen. Konsep pemisahan ini bertujuan agar strategi pemasaran online dapat tepat sasaran.

\section{Memilih media digital yang tepat}

Setelah diputuskan siapa yang menjadi segmen usaha dagang ini maka selanjutnya memilih media apa yang akan digunakan dalam pemasaran online-nya. Terdapat empat media online yang dapat digunakan oleh usaha dagang ini, yaitu:

1) Website: adalah media halaman selain menyampaikan informasi, bisa digunakan untuk jual beli memasarkan produk dan jasa. Website dibuat oleh sang pemilik dengan akses yang bebas untuk mendesain dan mengisi konten apa saja yang diperlukan. Tim mengusulkan agar mitra membuat web usaha dagang ini agar tiap konsumen dapat mengetahui produk perusahaan dan dapat menarik pelanggan potensial untuk mengenal usaha dagang ini. Usaha dagang ini dapat bekerjasama dengan web designer untuk menghasilkan website yang baik.

2) Marketplace: situs yang disediakan sebagai tempat jual beli secara aman, semua penjual bisa membuat toko online di marketplace dan pembeli juga bisa bebas melakukan transaksi dengan sistem yang ditentukan oleh pihak marketplace. Tim mengusulkan agar mitra juga melakukan pemasaran produknya melalui marketplace, seperti Tokopedia, Bukalapak, Shopee, Blibli, Lazada, dll. Hal ini dilakukan untuk menjangkau pasar konsumen yang jumlahnya sangat besar di Indonesia.

3) Toko online, tim mengusulkan kepada mitra, setelah mitra membuat website yang memuat produk perusahaan, maka selanjutnya produk tersebut dapat dijual secara online. Jadi website yang dibuat berfungsi sebagai toko yang memajang produk-produk secara online agar 
pengunjung dapat leluasa memilih dan melakukan pemesanan secara online.

4) Media sosial: Media untuk berkumpul, berinteraksi, bersosialisasi secara online namun juga bisa digunakan sebagai akun bisnis. Tim juga menyarankan kepada mitra untuk membuat akun media sosial dalam upaya menjangkau pelanggan potensial yang belum tergarap oleh usaha ini, misalnya melalui Instagram, facebook, atau media sosial lainnya.

\section{Membangun database customer}

Pada tahapan ini tim melakukan pendampingan dalam membuat database konsumen baik yang sifatnya konsumen potensial maupun aktual. Hal ini dilakukan untuk mempermudah mitra dalam mengkoordinasikan pelangaan dalam bagian-bagian tertentu yang diperlukan. Tim mengusulkan database yang dibuat menggunakan sistem komputer, artinya konsumen yang telah membeli produk perusahaan otomatis masuk dalam system usaha ini secara langsung termasuk didalamnya jumlah pembelian dapat terekapitulasi juga. Untuk pelanggan potensial juga terdata dengan baik agar pada saatnya nanti pelanggan tersebut akan menjadi pelanggan aktual bagi usaha ini.

\section{KESIMPULAN DAN SARAN}

\section{Kesimpulan}

Berdasarkan pelaksanaan kegiatan Pengabdian Kepada Masyarakat (PKM) ini diperoleh kesimpulan sebagai berikut:

1) Aneka Cahaya pelumas merupakan toko oli yang memenuhi wilayah Bekasi dan sekitarnya.

2) Toko ini mengalami masalah berupa penurunan nilai penjualan akibat pandemi.

3) Usaha toko ini masih menggunakan strategi pemasaran konvensional, yaitu menjual ketika dihubungi pembeli.

\section{Saran}

1) Memetakan segmen market bisnis anda

Usaha toko ini sebaiknya mengelompokkan jenis pelanggan berdasarkan cirinya, apakah pelanggan bisnis atau pelanggan non-bisnis atau pasar konsumen/produsen. Konsep pemisahan ini bertujuan agar strategi pemasaran online dapat tepat sasaran.

2) Memilih media digital yang tepat

Terdapat empat media yang mempunyai karakteristik yang berbeda-beda dan dapat dimanfaatkan untuk saling melengkapi satu sama lain dalam pemasaran online. Pemilihan media ini tergantung dari segmen pasar yang akan dituju.

3) Membangun database customer

Sebaiknya usaha ini membuat database menggunakan sistem komputer, artinya konsumen yang telah membeli produk perusahaan otomatis masuk dalam sistem usaha ini secara langsung termasuk didalamnya jumlah pembelian dapat terekapitulasi juga. Untuk pelanggan potensial juga terdata dengan baik agar pada saatnya nanti pelanggan tersebut akan menjadi pelanggan aktual bagi usaha ini.

\section{REFERENSI}

https://apjii.or.id/content/read/104/348/BULETIN-APJII-EDISI-22---Maret-2018

Dikdik, M. (2019). 10 Aplikasi Pembayaran Digital yang Paling Populer Saat Ini. Retrieved from https://carisinyal.com/: https://carisinyal.com/jenis- pembayaran- digital-populer/

Haluan, F. (2019). Keuntungan Digital Payment di Era Milenial. Retrieved from https://kepri.haluan.co/:https://kepri.haluan.co/2019/04/24/keuntungan-digital- paymentdi-era-milenial/

Nielsen (2016). Mobile money: from shopping to banking to payments, how mobile is 
transforming commerce around the world. Nielsen, p.May 2, 2017. Available at: www.nielsen.com/belen/insights/reports/2016/mobile-money.html/.

Phonthanukitithaworn, C., Sellitto, C. \& Fong, M.W.L., (2016). An investigation of mobile payment (mpayment) services in Thailand, Available at: https://www.emeraldinsight.com/doi/full/10.1108/APJBA-10-2014-0119.

Rahma, D. (2015). Internet Mengubah Hidup Jadi Lebih Baik . Retrieved from http://heydeerahma.com/: http://heydeerahma.com/internet- mengubah-hidup-jadi- lebihbaik/

Ramadhan, B. (2018). Indonesia Tempati Peringkat Pertama Negara Teraktif Menggunakan Aplikasi Mobile. Retrieved from https://www.goodnewsfromindonesia.id/:

We are social. (2019). Hootsuite (We are Social): Indonesian Digital Report 2019. Retrieved from https://andi.link/hootsuite-we-are-social- indonesian-digital- report-2019/ 
Seminar Nasional Hasil Penelitian dan Pengabdian Kepada Masyarakat 2021

Pengembangan Ekonomi Bangsa Melalui Inovasi Digital Hasil Penelitian dan

Pengabdian Kepada Masyarakat

Jakarta, 21 Oktober 2021

(halaman kosong) 